\title{
Student-Led Adaptation of Improvement Science Learning During the COVID-19 Pandemic
}

Sherry Liang, MD | Linh Nhat Taylor, BS | Reem Hasan, MD, PhD

PRiMER. 2020;4:20.

Published: 9/16/2020 | DOI: 10.22454/PRiMER.2020.536861

\section{Abstract}

Introduction: In response to the COVID-19 pandemic and the restriction of students participating in face-toface instruction, two medical students rapidly adapted a preclinical curriculum that virtually teaches improvement science and equips learners with the knowledge to address patient needs.

Methods: Eight first-year medical students participating in a longitudinal patient navigation and health systems science program completed 15 interactive video sessions. After learning about the Model for Improvement and various quality improvement tools, students worked in teams of four to conduct several plan-do-study-act cycles. Postsession surveys captured student satisfaction, session feedback, and reflections about conducting improvement work. Two medical students then applied conventional content analysis to identify themes to describe the data.

Results: Student projects focused on addressing patients' health care and social resource needs through telephone and electronic interactions. Five themes were identified in the survey results: (1) learning by doing in the dynamic nature of improvement work; (2) enjoyment of virtual team-based learning; (3) project relevance to COVID-19; (4) utility of quality improvement tools; and (5) continuous curriculum improvement with student feedback.

Conclusions: In this student-led endeavor, we implemented a virtual improvement curriculum where first-year medical students apply improvement science knowledge to patient needs during the COVID-19 pandemic. Results demonstrate the feasibility of teaching improvement in a virtual setting where learning is action-based with project work being relevant to health care priorities. Our work provides a framework for others to continue teaching this integral component of medical education.

\section{Introduction}

The COVID-19 pandemic has created many changes in how medical students learn and contribute to patient care. ${ }^{1}$ Improvement teaching is a vital component of medical education, and is ideally action-based, combining didactic and project work linked to local health system improvement efforts, with assessment of learner outcomes and modeling continuous improvement in educational processes. ${ }^{2-4}$ We describe a new approach of teaching improvement whereby students apply didactic knowledge in a value-added manner during COVID-19. The Student Navigator Project (SNaP) is a longitudinal integrated preclinical program at a large urban academic medical center; $\mathrm{SNaP}$ includes improvement science learning where students complete mentored clinical improvement projects and collaborate interprofessionally with clinic staff. ${ }^{5}$ In this report, we describe how a student-led effort rapidly adapted this clinic-based improvement curriculum into a virtual experience where first-year students respond to patient 
needs while adhering to social distancing measures. This intervention serves as a model for others to implement virtually at their own institutions.

\section{Methods}

\section{Educational Response}

Upon transition to virtual-only learning in March 2020, two medical students convened with the SNaP director to adapt the improvement curriculum to be delivered virtually. All eight first-year medical students (age range 23-29 years; seven females, one male) in the SNaP cohort participated. Students had previously established a 1-3-month relationship with one to two patients as part of their patient navigation work and received an introduction to improvement science through the Institute for Healthcare Improvement $(\mathrm{IHI})$ Open School Modules. ${ }^{6}$

\section{Curriculum Description and Implementation}

Figure 1 shows curriculum objectives. The curriculum involved two phases: project-based learning followed by scholarly synthesis of work (Table 1). We utilized WebEx, a virtual meeting platform, and Box, an encrypted cloud drive with Microsoft Office applications. Didactics focused on purposefully linking improvement concepts to the impact of COVID-19 on the students' patient navigation work. For the 3-question project brainstorming, students applied the Model for Improvement ${ }^{7}$ to the pandemic context by identifying a problem related to their patients' needs, brainstorming change ideas, and generating measures. In teams of four, students spent approximately 2 months completing three plan-do-study-act (PDSA) cycles. Students utilized a shared Excel sheet on Box to record their project work, which included a project management template to record each phase of the PDSA cycle. WebEx meetings consisted of large-group learnings and separate project team discussions facilitated by a project coach. In the scholarly synthesis of work phase, students reviewed quality improvement tools and applied them to their projects. Students created posters to highlight key project learnings and to present at scholarly venues.

\section{Curriculum Evaluation}

Students completed a voluntary, anonymous, online survey after each session that captured student satisfaction, session feedback, and reflections about the session content. A conventional content analysis approach was utilized to identify themes. Two lead medical students reviewed the survey results and developed preliminary themes. The students analyzed later surveys in a similar manner, adding new codes only if necessary. The Institutional Review Board determined this activity exempt from oversight. Curriculum materials are available on the Society of Teachers of Family Medicine Resource Library. ${ }^{8}$

\section{Results}

The findings in this report reflect data collected from March 30, 2020 to June 1, 2020 during the project-based learning phase. Student projects focused on addressing patients' health care and social resource needs through telephone and/or electronic interactions.

Table 2 outlines qualitative results of the postsession survey completed by students at an average response rate of $70 \%(n=8)$. Students reported enjoying a session $87 \%$ of the time, with the remainder as enjoying the session somewhat. We identified five themes: (1) learning by doing in the dynamic nature of improvement work; (2) enjoyment of virtual team-based learning; (3) project relevance to COVID-19; (4) utility of quality improvement tools; and (5) continuous curriculum improvement with student feedback.

\section{Conclusions}

In our student-led endeavor to implement a virtual improvement curriculum, first-year medical students learned and applied improvement science knowledge to patient needs during the COVID-19 pandemic. With the use of a virtual meeting platform and secure cloud drive for document, our program demonstrated the feasibility of teaching 
improvement in a virtual setting where learning is action-based with project work linked to health care priorities, evident by the two projects carried out by students as a product of this curriculum. Learners reported satisfaction with virtual group discussions and conducting projects relevant to their patients and current events (Table 2, themes 2 and 3). Learner reflections also highlighted the dynamic, trial-by-learning nature of improvement work (Table 2 , theme 1). These methods allowed medical students to engage in issues related to COVID-19, further building competence and confidence in health systems improvement. While it is unclear whether the projects will generate a measurable impact on patients, our results nonetheless indicate the program's salient effect on students by instilling the knowledge, skills (evident in theme 4, Table 2), and positive attitude to lead improvement work (shown by themes 1,2 , and 3, Table 2). Our role modeling of continuous improvement by utilizing student feedback to rapidly adapt the curricular content in real time also fulfills an important educational principle (proven by theme 5 , Table 2). ${ }^{2}$ Notably, students voiced concerns about session length, outside classwork volume, and insufficient practice with certain quality improvement tools, which helped to shape latter parts of the curriculum.

This study is limited by self-reported qualitative data and a small sample size of self-selected learners. The curriculum operates within a program where first-year medical students can gain longitudinal experience as patient navigators and therefore intimately understand patient needs during COVID-19. In the absence of such program and existing patient relationships, it may be challenging for early students to identify relevant and feasible project topics. Lastly, a conventional approach to content analysis may also fail to identify key categories.

In conclusion, this student-led implementation of a virtual curriculum engaged first-year medical students in improvement work that addressed patient needs during the COVID-19 pandemic. Engaged in virtual team-based discussions, students developed reflections about improvement work early in their clinical training. Future work should explore ways to incorporate more students and expand on project topics that align with both clinical and educational priorities.

\section{Tables and Figures}


Figure 1: Learning Objectives of a Rapidly-Adapted Virtual Improvement Curriculum for First-Year Medical Students

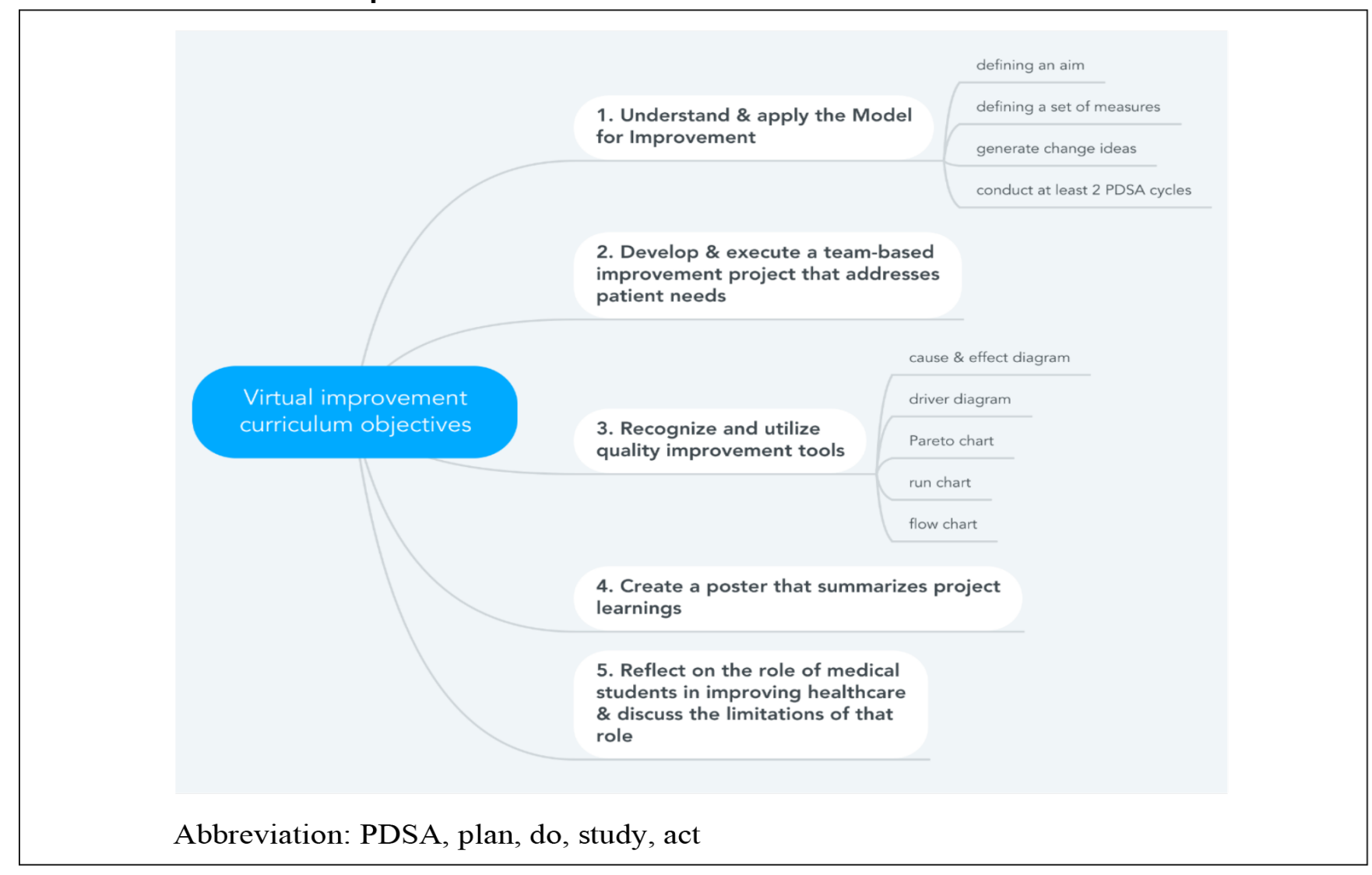


Table 1: Roadmap of Curriculum Delivered in Two Phases: Project-Based Learning Followed by Synthesis of Work (Materials Are Available in the STFM Resource Library)

\begin{tabular}{|c|c|c|c|c|c|}
\hline \multicolumn{6}{|c|}{ Curriculum Roadmap } \\
\hline Phase & Date & $\begin{array}{l}\text { Time } \\
\text { (Hours) }\end{array}$ & Topic & Materials & $\begin{array}{l}\text { Postsession } \\
\text { Work }\end{array}$ \\
\hline \multirow{9}{*}{1} & Mar 30 & 1 & $\begin{array}{l}\text { Curriculum overview } \\
\text { Run chart didactics } \\
\text { Pareto chart didactics and exercise }\end{array}$ & $\begin{array}{l}\text { Microsoft PowerPoint } \\
\text { Google Trend } \\
\text { Excel }\end{array}$ & $\begin{array}{l}\text { IHI QI } 103 \text { module } \\
\text { Pareto data } \\
\text { collection }\end{array}$ \\
\hline & Apr 6 & 1 & $\begin{array}{l}\text { Review Pareto data } \\
\text { Driver diagram didactics and exercise }\end{array}$ & $\begin{array}{l}\text { Excel } \\
\text { Microsoft PowerPoint }\end{array}$ & $\begin{array}{l}\text { 3-question project } \\
\text { brainstorming }\end{array}$ \\
\hline & Apr 13 & 1 & $\begin{array}{l}\text { PDSA didactics } \\
\text { Introduction to project teams }\end{array}$ & Microsoft PowerPoint & - \\
\hline & Apr 20 & 1 & \multirow{6}{*}{$\begin{array}{l}\text { Project team work: complete at least two } \\
\text { PDSA cycles }\end{array}$} & \multirow{6}{*}{$\begin{array}{l}\text { Microsoft Excel } \\
\text { project management } \\
\text { template }\end{array}$} & \multirow{6}{*}{$\begin{array}{l}\text { Plan and/or execute } \\
\text { tests of change }\end{array}$} \\
\hline & Apr 27 & 2 & & & \\
\hline & May 11 & 1 & & & \\
\hline & Jun 1 & 2 & & & \\
\hline & Jun 8 & 1 & & & \\
\hline & Jun 15 & 1 & & & \\
\hline \multirow{6}{*}{2} & Jun 29 & 1 & Pareto chart & \multirow{4}{*}{ Microsoft PowerPoint } & \multirow{4}{*}{$\begin{array}{l}\text { Finish creating tools } \\
\text { for project }\end{array}$} \\
\hline & Jul 6 & 1 & Run chart & & \\
\hline & Jul 13 & 2 & $\begin{array}{l}\text { Driver diagram } \\
\text { Fishbone diagram }\end{array}$ & & \\
\hline & Jul 20 & 1 & Flow chart & & \\
\hline & Aug 10 & 1 & \multirow{2}{*}{ Poster } & \multirow{2}{*}{$\begin{array}{l}\text { Poster examples } \\
\text { from previous years }\end{array}$} & \multirow{2}{*}{ Finish poster } \\
\hline & Aug 17 & 1 & & & \\
\hline
\end{tabular}

Abbreviations: IHI, Institute for Healthcare Improvement; QI, quality improvement; PDSA, plan, do, study, act. 
Table 2: Qualitative Results of Postsession Surveys

\begin{tabular}{|c|c|c|}
\hline Theme & Student Comments & Significance of Theme \\
\hline $\begin{array}{l}\text { Theme 1: Learning by } \\
\text { doing in the dynamic } \\
\text { nature of improvement } \\
\text { work }\end{array}$ & $\begin{array}{l}\text { - Revisiting and adjusting our aim as we progress } \\
\text { in the project is important. } \\
\text { - Discussing the aim statement and potential } \\
\text { measured data was more dynamic than I } \\
\text { expected! } \\
\text { - [l] learned that you cannot get stuck in a [quality } \\
\text { improvement] QI project. } \\
\text { - [Our team] needs to simplify expectations and } \\
\text { take smaller steps with each PDSA } \\
\text { - [I learned] that an intervention can still be } \\
\text { considered successful even if achievement } \\
\text { of a goal was not tied directly to my action } \\
\text { as I had anticipated } \\
\text { QI can be a constant process in the health } \\
\text { care setting }\end{array}$ & $\begin{array}{l}\text { The dynamic nature of quality improvement was well } \\
\text { recognized, understood, and received by students. } \\
\text { This theme emerged from students' comments not } \\
\text { just on the process of gradual improvement in quality } \\
\text { improvement but also the dynamic nature of working } \\
\text { on a project in a virtual, real-time platform. }\end{array}$ \\
\hline $\begin{array}{l}\text { Theme 2: Enjoyment } \\
\text { of virtual team-based } \\
\text { learning }\end{array}$ & $\begin{array}{l}\text { - The session] was productive - felt exciting to } \\
\text { have a plan moving forward for a project, } \\
\text { we now have created our initial needs } \\
\text { assessment survey } \\
\text { - As ever, I love seeing how our project evolves } \\
\text { with group discussion } \\
\text { - I appreciated the unstructured time to ask } \\
\text { questions and talk about our work } \\
\text { - I learned a lot about different measurements } \\
\text { and had fun discussion what we would do } \\
\text { next. } \\
\text { - I enjoyed the space allowed for discussion, } \\
\text { which was much more substantive than I } \\
\text { thought would be possible via telemeeting. } \\
\text { - I liked the ability to have a long discussion and } \\
\text { go back over pieces of the project that we } \\
\text { had not touched in a while } \\
\text { - I love that the discussion is very student driven } \\
\text { with the assistance of an outside faculty } \\
\text { facilitator to make sure we aren't forgetting } \\
\text { anything } \\
\text { - [I liked] live collaboration and plenty of } \\
\text { brainstorming }\end{array}$ & $\begin{array}{l}\text { This theme emerged as a surprise to the authors. } \\
\text { Virtual team-based learning in quality improvement } \\
\text { is not a tradition at our institution or of the SNaP } \\
\text { program. As we designed the curriculum, we } \\
\text { intentionally designed the sessions to increase } \\
\text { interactivity (finding the ideal session length, planning } \\
\text { to facilitate group discussion, planning for break-out } \\
\text { groups, etc). The positivity towards virtual team- } \\
\text { based learning is an encouraging sign for future } \\
\text { collaborative work within and among institutions. }\end{array}$ \\
\hline $\begin{array}{l}\text { Theme 3: Project } \\
\text { relevance to COVID-19 }\end{array}$ & $\begin{array}{l}\text { - I like that it is very relevant to the situation we } \\
\text { are in right now. It makes [me] more excited } \\
\text { to do the QI project than what we initially } \\
\text { came up with. } \\
\text { - I like that our QI session is relevant to currents } \\
\text { events and what we're going through now. }\end{array}$ & $\begin{array}{l}\text { With a pandemic taking over healthcare, the } \\
\text { economy, education, and lives, it became very } \\
\text { clear that medical education also needed to adapt } \\
\text { to current events. Higher quality education is } \\
\text { experienced when students enjoy the work; with } \\
\text { this project, we learned that students benefit from } \\
\text { medical education that is relevant and timely. }\end{array}$ \\
\hline $\begin{array}{l}\text { Theme 4: Utility of } \\
\text { quality improvement } \\
\text { tools }\end{array}$ & $\begin{array}{l}\text { - Revisiting [our] driver diagram was a good idea. } \\
\text { - I liked the presentation of graph format and } \\
\text { data types } \\
\text { - I like the flexibility in changing our project after } \\
\text { we saw that the Pareto diagram [exercise] } \\
\text { didn't really work with our small population. }\end{array}$ & $\begin{array}{l}\text { One of the five objectives of this curriculum was } \\
\text { to teach quality improvement tools and then } \\
\text { immediately allow students the opportunity to apply } \\
\text { that tool in a meaningful project. That objective was } \\
\text { clearly achieved as this theme emerged from the } \\
\text { students' comments. }\end{array}$ \\
\hline $\begin{array}{l}\text { Theme 5: Continuous } \\
\text { curricular improvement } \\
\text { with student feedback }\end{array}$ & $\begin{array}{l}\text { - I would have liked more time to look at the } \\
\text { Pareto chart. I was confused because the } \\
\text { values on the chart didn't seem to match the } \\
\text { frequency values on the tables, but I didn't } \\
\text { want to interrupt the class by asking that } \\
\text { question. } \\
\text { - I think } 45 \text { minutes is good enough time. I think } \\
\text { we are able to address a couple of concerns } \\
\text { and still have a good discussion. A little bit } \\
\text { more would be nice, but } 45 \text { is doable. } \\
\text { - More time! These meetings take longer over } \\
\text { WebEx than they would in person } \\
\text { - Less time in large groups--although if another } \\
\text { group is stuck, it's also understandable to } \\
\text { spend more time in large groups } \\
\text { - More examples on process measures \& } \\
\text { balancing measures. }\end{array}$ & $\begin{array}{l}\text { Adopting the continuous improvement theory } \\
\text { in designing the curriculum itself, we found that } \\
\text { students contributed formative feedback that allowed } \\
\text { us to continually improve the curriculum as we } \\
\text { progressed. }\end{array}$ \\
\hline
\end{tabular}




\section{Acknowledgments}

The authors thank Kanwar Thind, MPH, and the students who participated in this curriculum.

\section{Author Affiliations}

Sherry Liang, MD - Departments of Internal Medicine and Psychiatry, Tulane University, New Orleans, LA Linh Nhat Taylor, BS - Oregon Health \& Science University School of Medicine, Portland, OR

Reem Hasan, MD, PhD - Department of Medicine, Division of General Internal Medicine and Geriatrics I and Department of Pediatrics, Division of General Pediatrics, Oregon Health \& Science University, Portland, OR

\section{References}

1. Rose S. Medical Student Education in the Time of COVID-19. JAMA. 2020;323(21):2131. doi:10.1001/jama.2020.5227

2. Armstrong G, Headrick L, Madigosky W, Ogrinc G. Designing education to improve care. Jt Comm J Qual Patient Saf. 2012;38(1):5-14. doi:10.1016/S1553-7250(12)38002-1

3. Dumenco L, Monteiro K, George P, McNicoll L, Warrier S, Dollase R. An interactive quality improvement and patient safety workshop for first-year medical students. MedEdPORTAL. 2018;14(1):10734. doi:10.15766/mep_2374-8265.10734

4. Bartlett CS, Huerta SA. Creating change: an experiential quality improvement and patient safety curriculum for medical students. MedEdPORTAL. 2018;14(1):10660. doi:10.15766/mep_2374-8265.10660

5. Hasan R, Caron R, Kim H, et al. The Student Navigator Project (SNaP): preparing students through longitudinal learning. Med Sci Educ. 2020:1-9. doi:10.1007/s40670-020-00957-6

6. Institute for Healthcare Improvement. IHI Open School Sources website. http://app.ihi.org/Imsspa /\#/6cb1c614-884b-43ef-9abd-d90849f183d4. Accessed May 10, 2020.

7. Langley GL, Nolan KM, Nolan TW, et al. The improvement guide: a practical approach to enhancing organizational performance. 2nd ed. Jossey-Bass; 2009.

8. Liang S, Taylor NT, Hasan R. Quality improvement tool exercises using COVID-19 examples. STFM Resource Library; 2020.

Copyright $\odot 2020$ by the Society of Teachers of Family Medicine 